$\xi_{p-1}$

\title{
Review on Nickel Aluminide based Bond Coat Properties and Oxidation Performance for Thermal Barrier Coating (TBC) Application
}

\author{
NF. Kadir ${ }^{1 *}$, A. Manap ${ }^{2}$, M. Satgunam ${ }^{3}$, Nurfanizan Mohd Afandi ${ }^{4}$ \\ ${ }^{1}$ Mechanical Engineering Department, College of Engineering, Universiti Tenaga Nasional, 43000 Kajang, Selangor, Malaysia \\ ${ }^{2}$ Institute of Power Engineering (IPE), Universiti Tenaga Nasional, 43000 Kajang, Selangor, Malaysia \\ *Corresponding author E-mail: Nurul.Fateha@ uniten.edu.my
}

\begin{abstract}
Thermal Barrier Coating (TBC) as protective coatings are applied to maintain efficiency and prevent structural failures mainly in gas turbine system. This paper reviews on recent bond coating from Nickel aluminide bond coat with addition of Reactive Elements (RE). This paper also reviews the major concern in TBC with presence of different Reactive Element (RE) added in term of RE composition, properties and oxidation test performance. Recent studies are more focusing on few REs including Ce, Hf, La, Y and $\mathrm{Zr}$ based on oxidation property test results. The comparisons clearly show that ceramics addition are superior for bond coat mechanical and thermal properties improvement while $\mathrm{RE}$ addition such as $\mathrm{Ce}$ and $\mathrm{Zr}$ present excellent oxidation performance at $900^{\circ} \mathrm{C}$ and above.
\end{abstract}

Keywords: Bond coat; Nickel Aluminide; Oxidation behavior; Reactive Element; Thermal Barrier Coating

\section{Introduction}

Thermal Barrier Coating (TBC) is widely applied to protect hot sections of mechanical component for aerospace engines, aircraft engines and power generation industry. Recently, increasing in inlet temperature especially gas turbines in power plants is crucial to improve the efficiency of the overall gas turbine system. Significantly, in the mid 70s, the normal turbine inlet temperature in gas turbine is approximately $900^{\circ} \mathrm{C}$ [1]. However, over the years, this inlet temperature has been increasing up to $1400^{\circ} \mathrm{C}$. Normally, mechanical and thermal loading during service causes severe oxidation in rotating blades, combustor walls, and nozzle components. Hence, in order to sustain in this extreme high temperature and harsh oxidation internal environment, thermal barrier coatings (TBC) has been applied since last three decades.

TBC multi-layered system in Fig. 1 is applied in gas turbines to protect its underlying base metal by lowering the surface temperature of the substrate. Standard TBC multilayered systems consist of a ceramic top coat (TC) usually Yttria-stabilized zirconia (YSZ) and a metallic bond coat (BC). A protective oxide layer also known as Thermally-Grown Oxide (TGO) layer grows to improve the adhesion between top coat and NiAl bond coat [2]. This TBC provides engine efficiency by increasing inlet temperature for gas combustion and lowering operation temperature of super alloy substrate. Desirable thermal barrier effects are affected by a few factors such as ceramic coating material selection, coating structure design, and coating microstructure modification [3]. Nickelbased bond coat has been improving over the years to MCrAlY system ( $\mathrm{M}=\mathrm{Co}, \mathrm{Ni}$ or combination of both elements). It is believed that inter metallic compound such as alumina-forming base coatings especially at high temperatures $\left(\geq 900{ }^{\circ} \mathrm{C}\right)$ can be used as a bond coat in high oxidizing operating temperatures especially in gas turbines $[4,5]$. Authors in [6] have stated that the bond coat is supposed to be resistant to inter diffusion with substrate ideally, has minimal thermal mismatch and high creep strength in order to perform good bond coat properties and TBC system durability.

Many reports show that alumina formers such as Nickel aluminide bond coat can be improved by adding small amount of reactive elements such as yttrium, zirconium, lanthanum, hafnium and cerium [7]. Continuous effort is crucial in order to improve the efficiency of advanced gas turbine so that it can continue to operate under higher temperature than $1300^{\circ} \mathrm{C}$. Hence, selection of materials and its survivability level at extreme elevated temperature becomes the major objective in TBC system enhancement without having loss in term of functionality. Thus, development of structural and design for bond coat is one of the key successes to achieve high efficiency in gas turbine operation.

Alumina layer formed on the surface of materials plays vital role to provide excellent oxidation resistance at temperature as high as at $1000^{\circ} \mathrm{C}$ or even higher in nickel aluminides [8]. In fact, it is believed alumina is much more thermodynamically stable at high temperatures than $\mathrm{Cr}_{2} \mathrm{O}_{3}$ [8]. The aim of this paper is to review intermetallic Nickel aluminides as bond coat normally used in gas turbines. The effects of Reactive Element addition is reviewed in term of mechanical properties and oxidation behaviour at elevated extreme temperature range of $900-1400^{\circ} \mathrm{C}$.

\section{Bond Coat Development}

NiAl functions as a bond coat with high melting point about $1639^{\circ} \mathrm{C}$ as shown in Table 1 allows it becomes a promising material for high temperature applications such as in gas turbines [811]. In addition, from previous work by [12], it is clearly stated that the NiAl is usually chosen because it has high Young's modulus, good compressive strengths and excellent oxidation resistance [13]. In fact, NiAl based bond coat has great thermal conductivity 
in Ni-based super alloys [14]. This can be found in overlay coatings which is considered as a group of corrosion resistant alloys specifically designed as high-temperature surface barrier and are referred as MCrAlY coatings, where $\mathrm{M}$ is normally nickel (Ni) and/or cobalt ( $\mathrm{Co}$ ) and/or iron (Fe). Nickel aluminides advantages include its resistance to high temperature, good tensile and compressive yield strengths at $650-1100^{\circ} \mathrm{C}$, has superior creep resistance when in coarse grain size, excellent wear resistance at high temperatures $\left(2600^{\circ} \mathrm{C}\right)$ and the formation of $\mathrm{Al}_{2} \mathrm{O}_{3}$, on the surface by preoxidation provides good chemical compatibility in many extreme environments [8].

Table 1: Melting point of Nickel aluminides [11]

\begin{tabular}{|c|c|}
\hline Intermetallic & Melting point $\left({ }^{\circ} \mathrm{C}\right)$ \\
\hline $\mathrm{NiAl}$ & 1639 \\
\hline $\mathrm{Ni}_{3} \mathrm{Al}$ & 1395 \\
\hline $\mathrm{NiAl}_{3}$ & 854 \\
\hline $\mathrm{Ni}_{2} \mathrm{Al}_{3}$ & 1133 \\
\hline
\end{tabular}

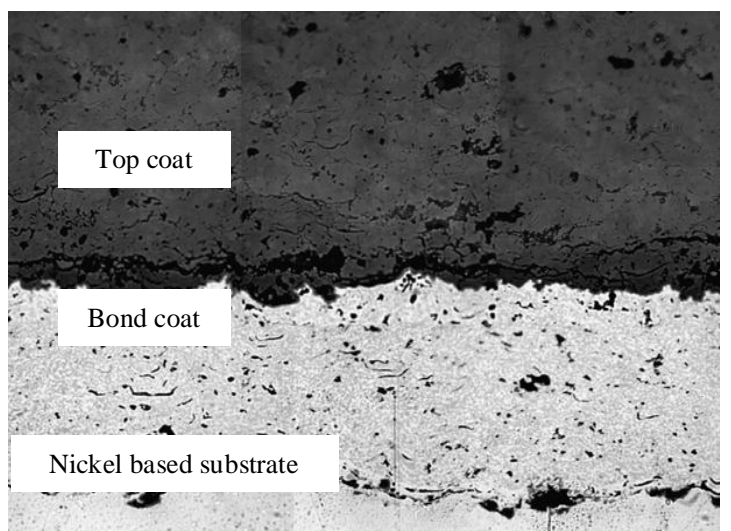

Fig.1: Thermal barrier coating system consists of top coat (upper), bond coat (middle) and substrate (lower).

\section{Ceramics in Bond Coat}

Promising material, $\mathrm{NiAl}$ are known for its advantages such as low density, high melting temperature, high resistance to oxidation at high temperatures (to about $1200^{\circ} \mathrm{C}$ ) and stable in an increased temperature environment. However, this intermetallic compound has poor toughness at room temperature and inadequate strength and creep resistance at elevated temperature especially to withstand extreme hot working environment overcome by modifying its chemical composition to ease mechanical processing [15]. Ceramics can offer excellent thermal and chemical resistance at both ambient and elevated temperatures thus becomes one of the best crack-healing materials. Intermetallic-based composites reinforced with ceramic particles are attractive topic within material science for its diverse structure, properties and manufacturing processes $[13,16]$. They are widely used in aircraft, aerospace, metallurgical and power generation industries. The following subtopics review the properties and oxidation performance for ceramic-metal composites.

\subsection{Effect of Ceramics in Bond Coat Properties}

Elastic mechanical properties experimental results in Fig. 2 and 3 show that hot-pressed $\mathrm{NiAl} / \mathrm{Al}_{2} \mathrm{O}_{3}$ shows the highest value of 219 $\mathrm{GPa}$ as compared with $\mathrm{NiAl}$ of $183 \mathrm{GPa}$ at $1400^{\circ} \mathrm{C}$. The authors stated that the application of higher external pressure of $30 \mathrm{MPa}$ allows to obtain a low-porosity structure and a low number of isolated spherical pores. In addition, the authors concluded that alumina particles increases the bending strength of the composite through SEM observations $[13,16]$. An investigation has been done to determine mechanical properties such as elastic and tensile strength of $\mathrm{NiAl} / \mathrm{Al}_{2} \mathrm{O}_{3}$ composite by influence of compacting pressure, sintering temperature and time. From the study,
$\mathrm{NiAl} / \mathrm{Al}_{2} \mathrm{O}_{3}$ composite shows the highest tensile strength of 227 $\mathrm{MPa}$ at 0.99 relative densities which is closely in agreement that the strength of sintered material increases with increasing density [17]. Furthermore, $\mathrm{NiAl} / \mathrm{Al}_{2} \mathrm{O}_{3}$ composite with $1 \mu \mathrm{m} \mathrm{NiAl}$ particles at $15 \%$ weight fraction showed the best fracture toughness of $\sim 8.1 \mathrm{MPa}^{1 / 2}$ about $80 \%$ improvement and exhibits crackhealing properties over pure alumina. Another study with $\mathrm{NiAl} / \mathrm{Al}_{2} \mathrm{O}_{3}$ by two consolidation techniques; explosive compaction and hot pressing allowed to obtain samples of high density (up to $99 \%$ of theoretical one) and microhardness above $13 \mathrm{GPa}$ but simultaneously preserved the nanocrystalline structure of material [18].
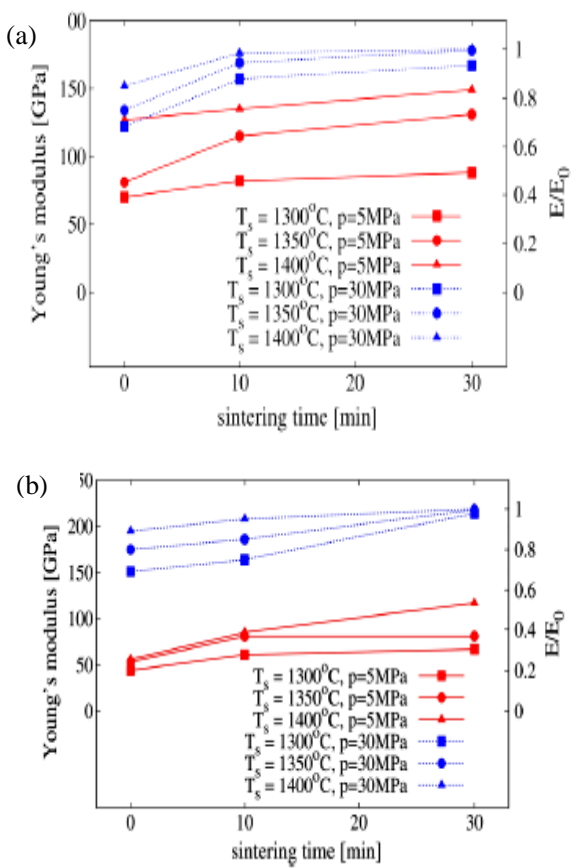

Fig. 2: Experimental results of Young's Modulus between (a) pure $\mathrm{NiAl}$ (b) $\mathrm{NiAl} / \mathrm{Al}_{2} \mathrm{O}_{3}\left(\mathrm{E}_{\mathrm{o}}\right.$ - the Young's modulus of a fully dense material [13]

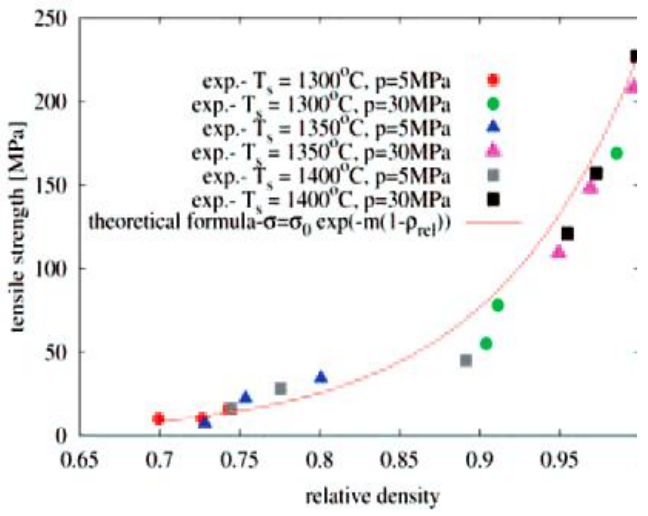

Fig. 3: Tensile strength of $\mathrm{NiAl} / \mathrm{Al}_{2} \mathrm{O}_{3}$ composite results after indirect tensile strength test at different sintering temperature and pressure [17]

Table 2: Properties studies related to bond coat in Thermal Barrier Coating

\begin{tabular}{|c|c|c|}
\hline Mechanical properties & Thermal properties & Oxidation properties \\
\hline Residual stress & $\begin{array}{c}\text { Coefficient of Thermal } \\
\text { Expansion (CTE) }\end{array}$ & TGO growth \\
\hline Hardness & Thermal conductivity & TGO compositions \\
\hline Surface roughness & & Mass change \\
\hline Elastic modulus & & Crack measurement \\
\hline Density & & \\
\hline Porosity & & \\
\hline
\end{tabular}




\subsection{Effect of Ceramics in Bond Coat Oxidation Per- formance}

Recently, bond coat materials mainly for land-based gas turbines, shows an observation with MCrAlY overlay coating resulted in a substantial improvement in furnace cycle lifetime with an increased roughness. It is well-known that oxide dispersion strengthening (ODS) results to improvements in oxidation behavior such as mass change and scale thickness. Hence, application of alumina is meant to overcome rapid oxidation diffusion within TBC system and lowering the TGO growth rate. Detailed investigation of isothermal behavior of compositionally graded $\mathrm{CoNiCrAlY} / \mathrm{Al}_{2} \mathrm{O}_{3} / \mathrm{YSZ}$ has been focused on oxidation kinetics and mechanism studies. The authors found out that the graded $\mathrm{CoNiCrAlY} / \mathrm{Al}_{2} \mathrm{O}_{3} / \mathrm{YSZ}$ shows inferior oxidation resistance as compared to duplex CoNiCrAlY/YSZ as complete spallation occurs at early stage of oxidation causes by lowest value of fracture toughness of the interface [19]. However, further study the effects of different oxide dispersions are evaluated in cyclic and isothermal oxidation at $1100^{\circ} \mathrm{C}$ shows the best performing composition was with a $2 \% \mathrm{Al}_{2} \mathrm{O}_{3}$ addition with lowest mass gains, best scale adhesion and limited $\beta$ phase depletion beneath the scale. This results study is affected by water vapour during cyclic testing. From Fig. 4, it is shown that CoNiCrAlY with $\mathrm{Al}_{2} \mathrm{O}_{3}$ gained lower mass at $0.12 \mathrm{mg} / \mathrm{cm}^{2}$ and formed thinner TGO layer compared with no addition to CoNiCrAlY. Thus, the authors stated that future work should focus on $\mathrm{Al}_{2} \mathrm{O}_{3}$ dispersions in $\mathrm{NiAl}$ based bond coat to avoid over doping issues [20] because of its excellent oxidation performance and capable to grow thin TGO layer. Comparison results between $\mathrm{CoNiCrAlY}$ and $\mathrm{CoNiCrAlY} / \mathrm{Al}_{2} \mathrm{O}_{3}$ are presented in Fig. 5 as follows.

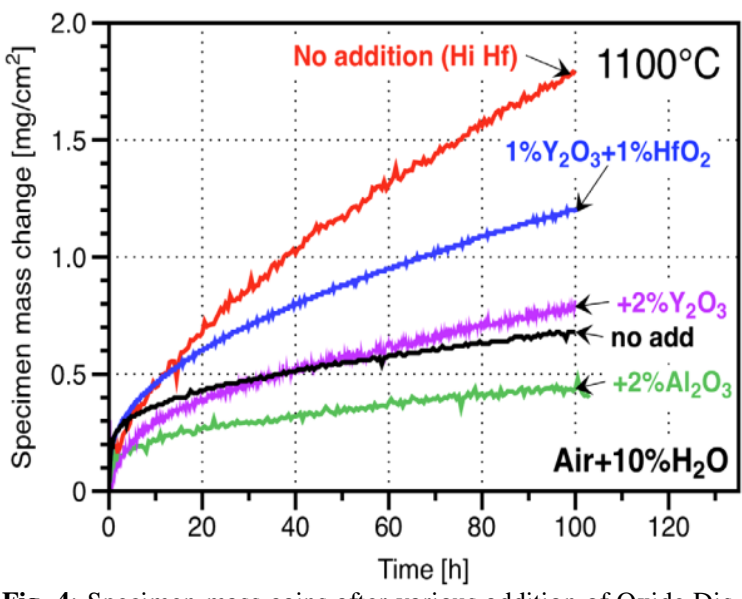

Fig. 4: Specimen mass gains after various addition of Oxide Dispersion Strengthening (ODS) into CoNiCrAlY during isothermal exposure at $1100{ }^{\circ} \mathrm{C}$ in air with $10 \% \mathrm{H}_{2} \mathrm{O}$ [20].
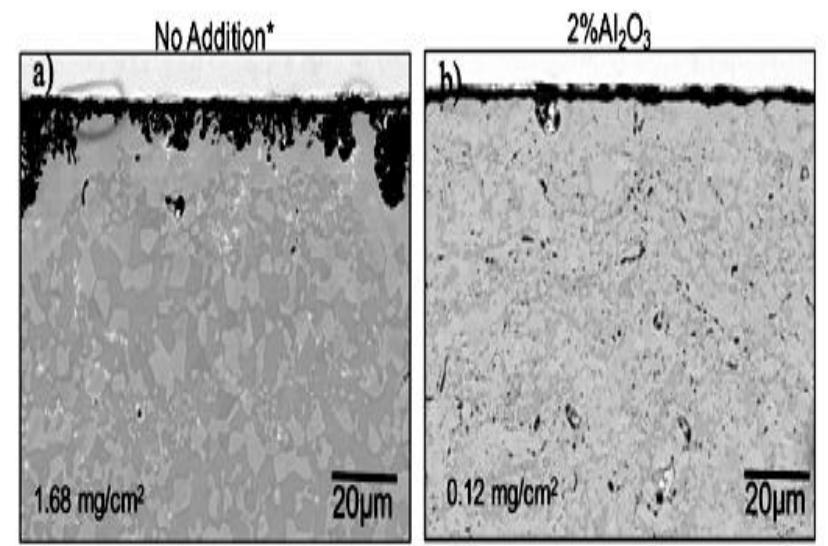

Fig. 5: SEM cross section images after $100 \mathrm{~h}$ of isothermal oxidation tes in wet air of (a) CoNiCrAlY (b) $\mathrm{CoNiCrAlY} / \mathrm{Al}_{2} \mathrm{O}_{3}$ [20]

\section{Reactive Element in Bond Coat}

Numerous researchers have stated that Reactive elements (RE) such as $\mathrm{Zr}$, Hf and rare earth elements (REE) such as Ce, Dy and La have been experimented to improve the high temperature oxidation resistance of chromia- and alumina forming alloys. Based on [21], rare earth (RE) elements and also defined as the lanthanides plus yttrium thus become emerging technology in various applications such as fuel cells, cell phones, medicine, and gas turbines. However, these elements have been standardized as reactive elements group based on their beneficial effects towards thermal coatings. Addition of reactive elements have significant effects namely Reactive Element Effects (REE) on $\mathrm{Al}_{2} \mathrm{O}_{3}$-forming alloys [22].

Authors in [23] stated that REs may consistently reduced the oxidation rate, with the magnitude of the benefit depending on the RE type. Authors in [24] stated that the presence of rare earth elements in which previously considered as rare is now growing which is easily available to get its supply thus improve micro structural refinement, grain size reduction, and homogenization of coating elements. According to researchers in [25], RE can be added either in the form of oxide-dispersion strengthening (ODS) alloy or by surface coating of these oxides, thus significantly improved scale adherence to metal-substrate when subjected to high temperature corrosion as it segregates of reactive element to the alloy-oxide interface to strengthens the alloy-scale bond [26].

It is believed that chemical modifications to the $\mathrm{NiAl}$ based bond coat with proper amount of RE addition that might improve adhesion and inhibit oxide formation [27]. The metallic coating systems such as diffusion aluminide and $\mathrm{NiAl}$ overlay coating with $\mathrm{RE}$ additives are believed to have the capability to form a thin, strong and uniform alumina layer, which acts as an effective barrier to prevent oxidation and deterioration of the substrate alloys. According to [28], have stronger oxide-forming ability than $\mathrm{Al}$ may effect oxidation performance in Nickel-based alloy. RE addition has capability to reduce oxidation rate on $\mathrm{Al}$ outward diffusion and this effect may happen when RE ions are relatively larger and has low solubility. $\mathrm{RE}$ addition will segregate to $\mathrm{Al}_{2} \mathrm{O}_{3}$ grain boundaries make them hardly to diffuse than $\mathrm{Al}$ ions and outward diffusion of $\mathrm{Al}$ is suppressed. Thus, with the mechanism, slower inward diffusion of oxygen becomes predominant element and lower the oxidation rate during high exposure [29].

\subsection{Effect of RE on Bond Coat Properties}

The effect of RE such as Y, La, Hf, $\mathrm{Zr}$ and Ce has been widely studied. The RE is can give effect to bond coat performance in term of composition added, microstructure size, and method of synthesize. It is agreed by [30] that reasonable amount of Ce, Hf, $\mathrm{Y}, \mathrm{La}$, and $\mathrm{Zr}$ addition is said should be kept low to 0.01-0.5 wt $\%$. This is supported by [31] that small amounts addition of REO can remarkably decrease crack susceptibility providing this addition must be critical and thorough experimental observations need to be done.

Results demonstrated by preliminary results from [32, 33] show that ceria may substitute $\mathrm{Al}$ site and has considerably improved the hardness, elastic modulus and thermal shock resistance of $\mathrm{NiAl}$ intermetallic coatings with optimum performance of $2 \mathrm{wt} . \%$ addition with fewer cracks, homogeneous in overall coating microstructure and relatively low uniform porosity along lamellar boundaries. However, the thermal-expansion mismatch studies between the top-coat and the metal (bond coat/super alloy) puts the top-coat in overall compression at room temperature [34]. It is believed that the presence of the dispersion particles so called Oxide-Dispersion Strengthening (ODS) may reduce the CTE at the interface as well [35]. Deeper understanding of material behavior at extreme temperature is essential using correct measurement techniques for properties such as density, fracture toughness and hardness [36] and summarized in Table 2. 


\subsection{Effect of RE on Bond Coat Oxidation Performance}

It is believed that TBC system with good bond coat material should has thinner TGO layer formed and has better oxidation behavior compared to TBC system that has thicker TGO layer [37]. According to [38], total oxidation resistance of TBC system depends on the top coat ceramic and its microstructures due to formation of mainly $\alpha$ - $\mathrm{Al} 2 \mathrm{O} 3$ based TGO at the interface of coating. In past studies done by [39, 40], coating oxidation kinetics is measured by the specific weight change and scale spallation during oxidation tests.

A study was done which by when nano-sized of $\mathrm{CeO}_{2}$ is added after 100 thermal shock cycles which shows that ceria not only improve the micro-hardness but reduces stress concentration of interface zone hence crack and scale spallation can be minimized as well [41]. Authors in [42, 43] also reported in their studies that $\mathrm{NiCrAlY}-\mathrm{CeO}_{2}$ with $0.4 \%$ addition of ceria coated superalloys showed better oxidation resistance and adherence at elevated temperature of $900^{\circ} \mathrm{C}$ as compared to bare superalloys. Furthermore,, authors in [44] stated that the larger size of Ce ions movement along the grain boundaries suppresses the diffusion of $\mathrm{Ni}$ or $\mathrm{Al}$ cations along the same paths which is dominant for the $\mathrm{NiO}$ or $\mathrm{Al}_{2} \mathrm{O}_{3}$ growth during oxidation. Authors in [45] have studied the effects addition of REs during high-temperature oxidation in which Dy- and Hf-doped two-phase NiAl alloys at $1100{ }^{\circ} \mathrm{C}$ with $0.1 \%$ addition respectively. NiAl with Dy doped shows better scale adhesion properties than Hf-doped NiAl.

$0.05 \%$ of nominal composition was experimented to observe the improvement of alumina adhesion and reduction of oxide scale rate with minor addition of $\mathrm{Hf}$ and other reactive elements $\mathrm{Zr}$ and La) $[46,47]$. However, experiment performed by [45] shows that only Dy doping can give reduction in the scale growth rate enhanced the oxide scale adhesion mainly due to the formation of oxide pegs at the scale/alloy interface while Hf doping had no significant effect on scale adhesion. In addition, this is closely related with authors in [48] in which they had stated that over doping with $\mathrm{Hf}$ may result in excess of $\mathrm{HfO}_{2}$ formation into the coating. This is because, low hafnium solubility also contributes to Hf-rich particle precipitation during oxidation [49]. However, approximately 0.3 at.\% addition will diminish beneficial effect of Hf at $1150{ }^{\circ} \mathrm{C}$ or $1100{ }^{\circ} \mathrm{C}$ after only 1001 -h cycles leads to detrimental performance of the relatively thin coatings [50]

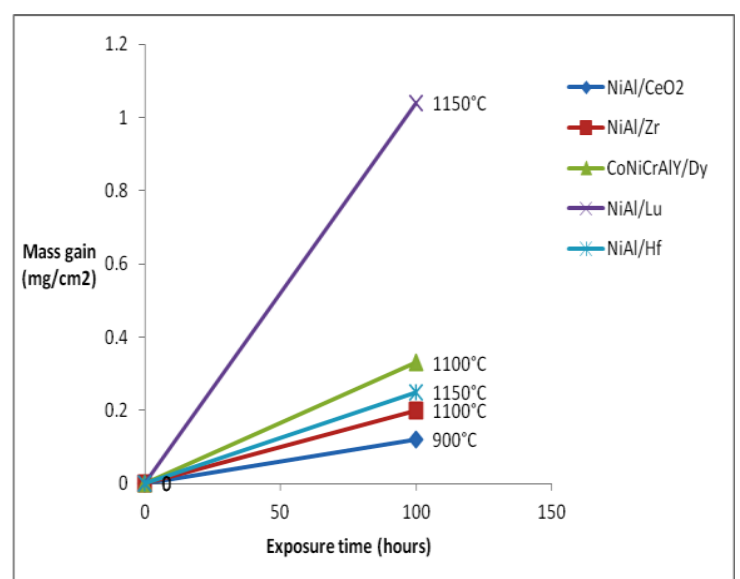

Fig.6: Graph comparison of NiAl based bond coating with Reactive Element presence at 100 hours of isothermal oxidation test [29, 51-53]

Based on work done by [54], the existed maximum crack length in the TBC and TGO thickness may be useful to the life prediction for overall TBC system. It is believed that the severe formation and growth of the $-\mathrm{Al}_{2} \mathrm{O}_{3} \mathrm{TGO}$ results in the depletion of $\mathrm{Al}$ in the bond-coat thus leads to formation of other oxides, such as $\mathrm{Ni}$ - and Co-containing spinels, $\mathrm{Y}_{3} \mathrm{Al}_{5} \mathrm{O}_{12}$, and $\mathrm{Y}_{2} \mathrm{O}_{3}$. The kinetics of TGO growth and bond coat rumpling (shape change) are unaffected by the rapid cycling of TBC system [55]. Authors reported that TGO growth may result in a constrained volume expansion that leads to compressive growth stresses then leads to crack nucleation [56]. Fig. 6 summarizes a few REs addition performance in bond coat.

\section{Summary}

More relevant studies are expected to create a slow growing, thin, dense and continuous $\mathrm{Al}_{2} \mathrm{O}_{3}$ protective layer in the bond coat to decrease spinel oxides such as $\mathrm{Ni}(\mathrm{Cr}, \mathrm{Al})_{2} \mathrm{O}_{4}$ and $\mathrm{NiO}$ formation on TGO layer with minimum use of Reactive Element additive. From the results, this composition may be as a based bond coat before addition of the Reactive Elements (RE) for future investigations. This shows that further extensive studies are needed to clarify the benificial effects of Ceria addition on improving the cyclic oxidation resistance of coatings.

However, deeper investigation on the reliability on composition of RE amount, oxidation kinetics and failure mechanisms should be investigated more in detailed. Other than that, life prediction of coatings and limiting spallation in TBC system are highly recommended to be tested in cyclic and isothermal oxidation tests at elevated operating temperature in the range of $900-1400^{\circ} \mathrm{C}$ in order to simulate in modern advanced gas turbines. From past recent results, ceramics addition into $\mathrm{NiAl}$ based bond coat will contribute to excellent properties; mechanical and thermal while $\mathrm{RE}$ addition into NiAl based bond coat results good oxidation performance provided with the suitable RE selection.

\section{Acknowledgement}

This study was supported by Fundamental Research Grant Scheme FRGS20160105 under Ministry of Higher Education (MOHE), BOLD grant, 10289176/B/9/2017/25 and Start-Up Grant RJO10289176/B/1/2017/9 under Universiti Tenaga Nasional.

\section{References}

[1] Johari, A.D.B., Characterization and Thermophysical Properties of Multi-Layered YSZ/REZ Thermal Barrier Coating Under Heat Treatment in Department of Mechanical Engineering 2017, Universiti Tenaga Nasional p. 119.

[2] Bobzin, K., et al., Microstructure behaviour and influence on thermally grown oxide formation of double-ceramic-layer EB-PVD thermal barrier coatings annealed at $1,300^{\circ} \mathrm{C}$ under ambient isothermal conditions. Materialwissenschaft und Werkstofftechnik, 2014. 45(10): p. 879-893.

[3] Li, C.-J., et al., The correlation of the TBC lifetimes in burner cycling test with thermal gradient and furnace isothermal cycling test by TGO effects. Journal of Thermal Spray Technology, 2017. 26(3): p. 378-387.

[4] Heuer, A.H., et al., On the growth of $\mathrm{Al} 2 \mathrm{O} 3$ scales. Acta Materialia 2013. 61(18): p. 6670-6683.

[5] Beyhaghi, M., et al., Effect of powder reactivity on fabrication and properties of $\mathrm{NiAl} / \mathrm{Al} 2 \mathrm{O} 3$ composite coated on cast iron using spark plasma sintering. Applied Surface Science, 2015. 344: p. 1-8.

[6] Yao, J., et al., Thermal barrier coating bonded by (Al2O3$\mathrm{Y} 2 \mathrm{O} 3) /(\mathrm{Y} 2 \mathrm{O} 3$-stabilized $\mathrm{ZrO} 2)$ laminated composite coating prepared by two-step cyclic spray pyrolysis. Corrosion Science, 2014. 80: p. 37-45.

[7] Wang, X., et al., The reactive element effect of ceria particle dispersion on alumina growth: A model based on microstructural observations. Sci Rep, 2016. 6: p. 29593.

[8] Deevi, S. and V. Sikka, Nickel and iron aluminides: an overview on properties, processing, and applications. Intermetallics, 1996. 4(5): p. 357-375.

[9] Shiomi, S., et al., Aluminide Coatings Fabricated on Nickel by Aluminium Electrodeposition from DMSO2-Based Electrolyte and Subsequent Annealing. Materials transactions, 2011. 52(6): p. 1216-1221

[10] Zhang, T., et al., Effects of Dy on the adherence of $\mathrm{Al} 2 \mathrm{O} / \mathrm{NiAl}$ interface: a combined first-principles and experimental studies. Corrosion Science, 2013. 66: p. 59-66. 
[11] Hultgren, R., et al., Selected values of the thermodynamic properties of binary alloys. 1973, National Standard Reference Data System.

[12] Tuan, W.H. and Y.P. Pai, Mechanical Properties of Al2O3-NiA Composites. Journal of the American Ceramic Society, 1999. 82(6): p. 1624-1626.

[13] Chmielewski, M., et al., Sintering behavior and mechanical properties of NiAl, Al2O3, and NiAl-Al2O3 composites. Journal of Materials Engineering and Performance, 2014. 23(11): p. 3875-3886.

[14] Udhayabanu, V., K. Ravi, and B. Murty, Ultrafine-grained, highstrength NiAl with $\mathrm{Al} 2 \mathrm{O} 3$ and $\mathrm{Al} 4 \mathrm{C} 3$ nanosized particles dispersed via mechanical alloying in toluene with spark plasma sintering. Materials Science and Engineering: A, 2013. 585: p. 379-386.

[15] Lin, C.-K., S.-S. Hong, and P.-Y. Lee, Formation of NiAl-Al2O3 intermetallic-matrix composite powders by mechanical alloying technique. Intermetallics, 2000. 8(9-11): p. 1043-1048.

[16] Huang, M., et al., Multifunctional Alumina Composites with Toughening and Crack-Healing Features Via Incorporation of $\mathrm{NiAl}$ Particles. Journal of the American Ceramic Society, 2015. 98(5): p. 1618-1625.

[17] Nosewicz, S., et al., The influence of hot pressing conditions on mechanical properties of nickel aluminide/alumina composite. Journal of Composite Materials, 2014. 48(29): p. 3577-3589.

[18] Oleszak, D., NiAl-A12O3 intermetallic matrix composite prepared by reactive milling and consolidation of powders. Journal of materials science, 2004. 39(16-17): p. 5169-5174.

[19] Subhasisa Nath, I.M., Jyotsna Dutta Majumdar Studies on Mechanical and Oxidation Resistance Properties of CoNiCrAlY/A12O3/YSZ Compositionally Graded Thermal Barrier Coating Developed by Air Plasma Spraying in Asia Thermal Spray Conference. 2014. p. 67-68.

[20] Unocic, K.A., et al., High-temperature behavior of oxide dispersion strengthening CoNiCrAlY. Materials at High Temperatures, 2017: p. 1-12.

[21] Evans, A.G., D.R. Clarke, and C.G. Levi, The influence of oxides on the performance of advanced gas turbines. Journal of the European Ceramic Society, 2008. 28(7): p. 1405-1419

[22] Navrotsky, A., et al., Thermodynamics of solid phases containing rare earth oxides. The Journal of Chemical Thermodynamics, 2015. 88: p. 126-141.

[23] Wu, Q., et al., Effect of Hf4+Concentration on Oxygen GrainBoundary Diffusion in Alumina. Journal of the American Ceramic Society, 2015. 98(10): p. 3346-3351.

[24] Jarvis, E.A. and E.A. Carter, The role of reactive elements in thermal barrier coatings. Computing in Science \& Engineering, 2002. 4(2): p. 33-41.

[25] Seal, S., et al., Ceria based high temperature coatings for oxidation prevention. JOM-e, 2000. 52(1): p. 1-8.

[26] Birks, N., G.H. Meier, and F.S. Pettit, Introduction to the high temperature oxidation of metals. 2006: Cambridge University Press.

[27] Emily A. Jarvis, E.A.C., The role of reactive elements in Therma Barrier Coatings. HPS and National Security, 2002.

[28] Bouchaud, B., et al., Correlations between electrochemical mechanisms and growth of ceria based coatings onto nickel substrates. Electrochimica Acta, 2013. 88: p. 798-806.

[29] Zhao, C., et al., Effect of alloyed Lu, Hf and $\mathrm{Cr}$ on the oxidation and spallation behavior of NiAl. Corrosion Science, 2017. 126: p 334-343.

[30] Hou, P.Y., The Reactive Element Effect - Past, Present and Future. Materials Science Forum, 2011. 696: p. 39-44.

[31] Quazi, M.M., et al., Effect of rare earth elements and their oxides on tribo-mechanical performance of laser claddings: A review. Journal of Rare Earths, 2016. 34(6): p. 549-564

[32] Wang, Y., et al., The effects of ceria on the mechanical properties and thermal shock resistance of thermal sprayed NiAl intermetallic coatings. Intermetallics, 2008. 16(5): p. 682-688.

[33] Guo, H., et al., Effect of Sm, Gd, Yb, Sc and Nd as reactive elements on oxidation behaviour of $\beta-\mathrm{NiAl}$ at $1200^{\circ} \mathrm{C}$. Corrosion Science, 2014. 78: p. 369-377.

[34] Padture, N.P., M. Gell, and E.H. Jordan, Thermal barrier coatings for gas-turbine engine applications. Science, 2002. 296(5566): p 280-284.

[35] Choo, H., P. Nash, and M. Dollar, Mechanical properties of NiAlAlN-Al 2 O 3 composites. Materials Science and Engineering: A, 1997. 239: p. 464-471.

[36] Kumar, V. and K. Balasubramanian, Progress update on failure mechanisms of advanced thermal barrier coatings: A review. Progress in Organic Coatings, 2016. 90: p. 54-82.
[37] Daroonparvar, M., et al., Improved Thermally Grown Oxide Scale in Air Plasma Sprayed NiCrAlY/Nano-YSZ Coatings. Journal of Nanomaterials, 2013. 2013: p. 1-9.

[38] Baskaran, T. and S.B. Arya, Role of thermally grown oxide and oxidation resistance of samarium strontium aluminate based air plasma sprayed ceramic thermal barrier coatings. Surface and Coatings Technology, 2017. 326: p. 299-309.

[39] Brandl, W., et al., The oxidation behaviour of sprayed MCrAlY coatings. Surface and Coatings Technology, 1996. 86: p. 41-47.

[40] Haynes, J., et al., Characterization of alumina scales formed during isothermal and cyclic oxidation of plasma-sprayed TBC systems at 1150 C. Oxidation of Metals, 1999. 52(1): p. 31-76.

[41] Wang, $\mathrm{H}$., et al., Effects of $\mathrm{CeO} 2$ nanoparticles on microstructure and properties of laser cladded NiCoCrAlY coatings. Journal of Rare Earths, 2010. 28(2): p. 246-250.

[42] Mahesh, R., R. Jayaganthan, and S. Prakash, A study on the oxidation behavior of $\mathrm{HVOF}$ sprayed NiCrAlY -0.4 wt.\% CeO 2 coatings on superalloys at elevated temperature. Materials Chemistry and Physics, 2010. 119(3): p. 449-457.

[43] Kamal, S., R. Jayaganthan, and S. Prakash, Mechanical and microstructural characteristics of detonation gun sprayed $\mathrm{NiCrAlY}+0.4 \mathrm{wt} \% \mathrm{CeO} 2$ coatings on superalloys. Materials Chemistry and Physics, 2010. 122(1): p. 262-268.

[44] Hongyu, C., et al., Effect of $\mathrm{CeO} 2$ on the Isothermal Oxidation of Electrode-posited Ni-Al Composite Coatings at $950{ }^{\circ} \mathrm{C}$. Rare Metal Materials and Engineering, 2015. 44(3): p. 571-575.

[45] He, J., et al., The role of Dy and Hf doping on oxidation behavior of two-phase $\left(\gamma^{\prime}+\beta\right) \mathrm{Ni}-\mathrm{Al}$ alloys. Corrosion Science, 2015. 98: p. 699-707.

[46] Guo, H., et al., Effect of co-doping of two reactive elements on alumina scale growth of $\beta-\mathrm{NiAl}$ at $1200^{\circ} \mathrm{C}$. Corrosion Science, 2014. 88: p. 197-208.

[47] Yan, K., H. Guo, and S. Gong, High-temperature oxidation behavior of $\beta-\mathrm{NiAl}$ with various reactive element dopants in dry and humid atmospheres. Corrosion Science, 2014. 83: p. 335-342.

[48] Wang, Y. and M. Suneson, Oxidation behavior of Hf-modified aluminide coatings on Inconel-718 at 1050 C. 2014.

[49] Zagula-Yavorska, M., M. Wierzbińska, and J. Sieniawski, Rhodium and Hafnium Influence on the Microstructure, Phase Composition, and Oxidation Resistance of Aluminide Coatings. Metals, 2017. $7(12)$.

[50] Liu, Z., et al., Cyclic oxidation resistance of $\mathrm{Ce} / \mathrm{Co}$ modified aluminide coatings on nickel base superalloys. Corrosion Science, 2015. 94: p. 135-141.

[51] Lan, H., et al., Effect of dysprosium addition on the cyclic oxidation behaviour of CoNiCrAlY alloy. Corrosion Science, 2011. 53(4): p. 1476-1483

[52] Hamadi, S., et al., Oxidation of a $\mathrm{Zr}$-doped $\mathrm{NiAl}$ bondcoat thermochemically deposited on a nickel-based superalloy. Materials at High Temperatures, 2009. 26(2): p. 195-198.

[53] Wang, X. and J.A. Szpunar, Effect of CeO2 Coating on the Isothermal Oxidation Behaviour of Ni-Based Alloy 230. Oxidation of Metals, 2017. 88(5-6): p. 565-582.

[54] Chen, W.R., et al., Pre-oxidation and TGO growth behaviour of an air-plasma-sprayed thermal barrier coating. Surface and Coatings Technology, 2008. 202(16): p. 3787-3796.

[55] Ahmadian, S. and E.H. Jordan, Explanation of the effect of rapid cycling on oxidation, rumpling, microcracking and lifetime of air plasma sprayed thermal barrier coatings. Surface and Coatings Technology, 2014. 244: p. 109-116.

[56] Schumann, E., et al., High-temperature stress measurements during the oxidation of NiAl. Oxidation of metals, 2000. 53(3): p. 259-272. 